\author{
S.A. Vizer, N.O. Akimbayeva, K.B. Yerzhanov \\ A.B. Bekturov Institute of Chemical Sciences, Almaty, Kazakhstan \\ (E-mail:s-w07@bk.ru)
}

\title{
«Green» chemistry methods in synthesis of flotation agents
}

\begin{abstract}
A review of the authors' own works devoted to the development of "green» methods of chemistry in the synthesis of various derivatives of monoethanolamine and diethanolamine, which are potential surface active substances and flotation agents, is made up. It is shown that the application of the "green» chemistry principles, for example, implication of 5 molar \% an organic phase transfer catalyst - tetrabutylammonium iodide in alkylation reactions makes it possible to significantly increase (in two to three times) the yields of target substances $\mathrm{N}$-alkylated derivatives of diethanolamine and monoethanolamine with a tenfold reduction in the duration of reactions and a lowering of the process temperature, which leads to a significant reduction in energy and labor costs. Synthesis of target flotation agents, for example, O-2-((dimethoxyphosphoryl)(2-hydroxyethyl)amino)ethylxanthate and sodium 2-dimethoxyphosphoryloxyethyl carbamate by the atomeconomic method - four-component reaction of the one-reactor interaction with a reduction in the number of stages from two to one also contributes to an increase in the total yield of target substances by 2-3 times.
\end{abstract}

Keywords: surface active substances, flotation agents, «green» chemistry, monoethanolamine and diethanolamine alkyl and dialkoxyphosphoryl derivatives, xanthate, carbamate.

\section{Introduction}

It is known, «green» chemistry means chemistry that efficiently processes raw materials (preferably renewable), excludes drains, avoids the use of toxic and harmful reagents and solvents in the production of chemical products and their application [1-3]. Acquiring new positions in technology development, «green» chemistry in the 21 st century has become a truly new way of thinking, a new philosophy, a new language that allows us to look at chemistry not only from utilitarian positions (production of products that have demand), but above all with humanitar positions [2]. It should be emphasized that «green» chemistry and ecology are not the same thing. On the contrary, the final goal of «green» chemistry is to negate the efforts of ecologists to remove those harmful emissions that are the main problem of almost all chemical (and not only chemical) industries. If ecologists try to neutralize the consequences created by chemistry, then the task of «green» chemistry is to provide such production in which harmful consequences are generally absent or minimized. The basic principles of «green» chemistry were formulated at the beginning of the 21 st century by Paul Anastas, one of the leaders of the US Environmental Protection Agency [3].

The current state of the technology of mineral processing makes it possible to ensure a fairly high degree of complex utilization of raw materials [4]. However, the further solution of the interrelated problems of more rational use of natural resources, ecology, energy and production management requires technologies for processing and enriching the mineral and other types of raw materials of a qualitatively new level [5]. Successful solution of the above problems is impossible without further improvement of the theory of enrichment processes, including selective opening and separation of minerals, separation of components of organic and inorganic substances from water [6]. The creation of new and modification of traditional flotation agents will allow increasing the extraction of target components from ores of nonferrous, noble and rare metals. In addition, from the economic point of view, the principle of creating new flotation agents should be the availability of starting reagents, which are easily obtained from petroleum hydrocarbons. In this regard, the problem of developing an efficient technology for the enrichment of polymetallic ores and the creation of highly effective, original and affordable flotation agents continues to be very actual [7].

It is known that the main groups of reagents used in the flotation of polymetallic sulphide ores are sulfhydryl anionic collectors - alkylxanthates, dithiocarbamates $[5,8]$ and dialkyldithiophosphates. Their collective ability largely depends on the structure and location of the hydrocarbon radical. This dependence has been studied in detail in a number of papers, from which it can be seen that a relatively small change in the structure of the collector molecule (for example, the elongation or isomerization of the hydrocarbon radical) leads to a significant change in the collection ability of the reagent [9-13]. 
The study of the properties of modified alkyl xanthates and dialkyl dithiophosphates is especially interesting, because a very limited number of publications are devoted to the study of the flotation properties of reagents of this kind, both in domestic and foreign literature.

\section{«Green» synthesis of alkyl diethanolamine derivatives}

As a result of our previous studies, high flotation activity and the selectivity of the action of a number of alkyl diethanolamine derivatives as additional collectors in flotation enrichment of sulfide polymetallic ores have been established. The disodium salt of N-octyl-N,N-bis(2-xanthateethyl)amine [14] and 2-[Nheptyl-N-(2-hydroxyethyl)amino] ethylxanthate sodium [15] significantly improve the quality of copper-lead concentrate at the processing of copper-lead-zinc-pyrite ore. N,N-Di(2-hydroxyethyl)aminononane [16] shows a high collecting activity in the flotation of lead-zinc-silver-containing ore, significantly increasing the extraction of lead, zinc and silver into the collective concentrate.

These reagents-collectors are obtained from commercially available diethanolamine in two stages via intermediate $\mathrm{N}$-alkylldi(2-hydroxyethyl)amines.

In order to increase the yields of intermediate $\mathrm{N}$-alkyldi(2-hydroxyethyl)amines in the preparation of compounds having flotation activity, an alkylation reaction of diethanolamine (DEA) with alkyl $\mathrm{C}_{4}-\mathrm{C}_{7}$ bromides $(\mathrm{AB})$ was carried out. Previously, the alkylation reaction of DEA was usually carried out by heating $\left(50-60{ }^{\circ} \mathrm{C}\right)$ in a water-alcohol medium for 3 days in the presence of a stoichiometric amount of potash [17]. At the same time, the yields of $\mathrm{C}_{4}-\mathrm{C}_{7}$ alkylated DEA derivatives ranged from 42 to $72 \%$.

Using one of the principles of «green» chemistry: «Catalytic systems and processes (as selective as possible) are better in all cases than stoichiometric ones» [2,3] alkylation of DEA in the presence of an organic phase transfer catalyst - tetrabutylammonium iodide was carried out. As a result of the reactions of alkylation of DEA at room temperature for 2 hours in an aqueous alcohol medium and a molar ratio of DEA:AB: $\mathrm{K}_{2} \mathrm{CO}_{3}: n-\mathrm{Bu}_{4} \mathrm{NI}=1: 1: 1: 0.1$ reagents, $81 \%$ of N-butyl-N,N-di(2-hydroxyethyl)amine, $87 \%$ of N-pentyl-N,N-di(2-hydroxyethyl)amine, $87 \%$ of N-hexyl-N,N-di(2-hydroxyethyl)amine, $92 \%$ of N-heptylN,N-di(2-hydroxyethyl)amine were obtained (Fig. 1).

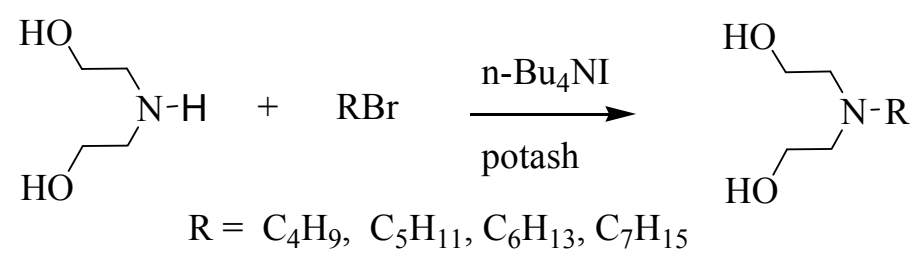

Figure 1. Synthesis of N-alkyl-N, N-diethanolamines

Based on the results obtained, it can be concluded that the alkylation reaction of DEA in accordance with the principles of «green» chemistry makes it possible to obtain $\mathrm{N}$-alkyldi(2-hydroxyethyl)amines selectively and in a high yield, with a significant reduction in the reaction time and a $30^{\circ} \mathrm{C}$ decrease in the process temperature, it leads to a reduction in energy and labor costs. At the same time, the yield of the target alkylaminoglycols almost doubles increases [18].

Application of the principles of "green» chemistry in the synthesis of sodium O-2-((dimethoxyphosphoryl)(2-hydroxyethyl)amino)ethylxanthate

In continuation of our research to obtain new diethanolamine-based surfactants, we performed a diethanolamine phosphorylation reaction by dialkyl phosphites, as shown in the diagram in Figure 2.

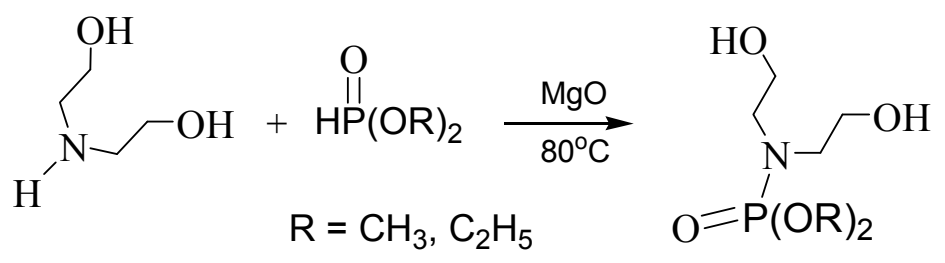

Figure 2. Scheme of phosphorylation of diethanolamine by dialkyl phosphites 
The diethanolamine phosphorylation reaction was carried out by reacting diethanolamine with a dialkyl phosphite in a benzene medium in the presence of magnesium oxide at a temperature of $80{ }^{\circ} \mathrm{C}$. As a result, dialkyl bis (2-hydroxyethyl) phosphoramidates were obtained in the yields of $67 \%$ and $65 \%$, respectively. The composition of the obtained phosphoramidates was confirmed on the basis of elemental analysis data, and the structure was confirmed on the basis of IR and NMR data of ${ }^{1} \mathrm{H}$ and ${ }^{13} \mathrm{C},{ }^{31} \mathrm{P}$ spectra [19]. In the IR spectra of synthesized phosphoramidates, intense bands of characteristic stretching vibrations of $\mathrm{P}=\mathrm{O}$ and $\mathrm{P}-\mathrm{O}-\mathrm{C}$ bonds in the region $1196,1162 \mathrm{~cm}^{-1}$ are observed, confirming the presence of a phosphoruscontaining radical in the molecule of the obtained compounds. The presence in the spectra of intense absorption bands in the region of $3267 \pm 3387 \mathrm{~cm}^{-1}$ confirms the presence of hydroxyl groups in the structure of phosphoramidates. In the PMR spectrum of dimethyl-bis(2-hydroxyethyl)phosphoramidate in $\mathrm{D}_{2} \mathrm{O}$ the protons of the $\mathrm{OCH}_{3}$ substituents are observed as a doublet at 3.20 and $3.23 \mathrm{ppm}$, the protons of $\mathrm{NCH}_{2}$ groups are resonated at 2.80-2.92 ppm, protons of $\mathrm{OCH}_{2}$ groups at $3.48 \mathrm{ppm}$, protons of $\mathrm{OH}$ groups at $4.70 \mathrm{ppm}$ in the form of a broadened singlet, which also confirms the reaction of the amine group.

In the PMR spectrum of diethyl-bis(2-hydroxyethyl)phosphoramidate in DMSO- $\mathrm{d}_{6}$, the protons of ethyl substituents manifest themselves as two groups of signals: a triplet at $1.15 \mathrm{ppm}$ with $\mathrm{J}=7.3 \mathrm{~Hz}$ and two quartets at $3.85 \mathrm{ppm}$ and $3.87 \mathrm{ppm}$ with the same SSIC, the protons of $\mathrm{NCH}_{2}$ groups are resonated at 2.95 and $2.98 \mathrm{ppm}$ in the form of two triplets with SSIC $6.1 \mathrm{~Hz}$, protons of $\mathrm{CH}_{2} \mathrm{OH}$ groups at $3.41 \mathrm{ppm}$ in the form of a triplet with $\mathrm{J}=6.3 \mathrm{~Hz}$, protons of $\mathrm{OH}$ groups at $4.70 \mathrm{ppm}$ in the form of a broadened singlet.

The two-dimensional COSY spectrum of dimethyl-bis(2-hydroxyethyl)phosphoramidate, shown in a Figure 3, made it possible to establish the homonuclear interactions of $\mathrm{H}-\mathrm{H}$ through three bonds and unambiguously confirm the structure of the obtained phosphamidate.

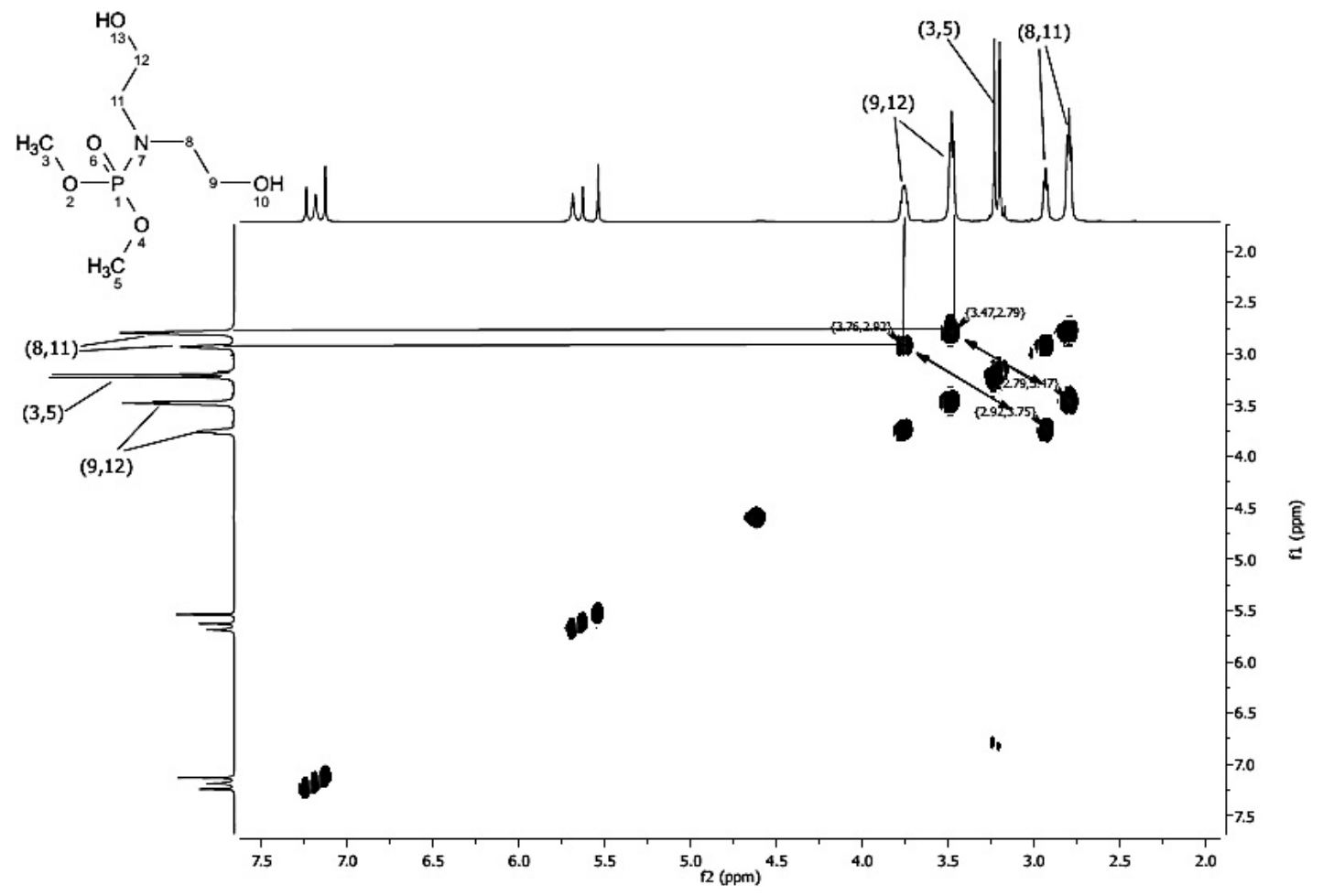

Figure 3. The two-dimensional COSY spectrum of dimethyl bis(2-hydroxyethyl)phosphamidate in $\mathrm{D}_{2} \mathrm{O}$

In the ${ }^{13} \mathrm{C}$ NMR spectrum of dimethyl-bis(2-hydroxyethyl)phosphoramidate, resonance signals in the region of $50.61 \mathrm{ppm}$ corresponding to the $\mathrm{OCH}_{3}$ groups, 57.44 and $59.82 \mathrm{ppm}$ corresponding to the $\mathrm{CH}_{2} \mathrm{OH}$ groups and the signals in the 39.87 and $41.05 \mathrm{ppm}$ which belong to the groups $\mathrm{CH}_{2} \mathrm{~N}$ are observed. In the ${ }^{13} \mathrm{C}$ NMR spectrum of diethyl-bis(2-hydroxyethyl)phosphoramidate resonance signals are observed in the $16.4 \mathrm{ppm}$ region corresponding to the $\mathrm{OCH}_{2} \mathrm{CH}_{3}$ groups, at $60.28 \mathrm{ppm}$. $-\mathrm{OCH}_{2} \mathrm{CH}_{3}$ groups and signals in the region of $49.28 \mathrm{ppm}$ belong to the $\mathrm{CH}_{2} \mathrm{~N}$ groups, the signals at $61.78 \mathrm{ppm}$. - to $\mathrm{CH}_{2} \mathrm{OH}$ groups.

In the ${ }^{31} \mathrm{P}$ spectrum of dimethyl-bis(2-hydroxyethyl)phosphoramidate, only one signal is observed in the region of $8.86 \mathrm{ppm}$, and in the ${ }^{31} \mathrm{P}$ spectrum of diethyl-bis(2-hydroxyethyl)phosphoramidate - one signal in the region of $11.17 \mathrm{ppm}$ corresponding to the dialkoxyphosphamide group is observed. 
Further conversion of dimethyl bis(2-hydroxyethyl)phosphamidate to sodium xanthate was carried out by reacting phosphamidate (FA) with carbon disulphide and sodium hydroxide at room temperature and the molar ratio of $\mathrm{FA}: \mathrm{CS}_{2}: \mathrm{NaOH}=1: 1: 1$ reagents in an alcohol medium, as shown in Figure 4. Sodium O-2-((dimethoxyphosphoryl)(2-hydroxyethyl)amino)ethylxanthate was obtained in a yield of $28 \%$, m.p. $78^{\circ} \mathrm{C}$. Since the yield of dimethyl-bis(2-hydroxyethyl)phosphamidate in the first stage was $67 \%$, the total yield of xanthate in two stages is $19 \%$.<smiles>COP(=O)(OC)N(CCO)CCO</smiles>

Figure 4. Scheme of dimethyl-bis(2-hydroxyethyl)phosphamidate reaction with carbon disulphide and sodium hydroxide

Since the development of «green» methods for the synthesis of diethanolamine derivatives is one of the goals of our studies, we studied a one-reactor method for carrying out a four-component reaction of diethanolamine, dimethyl phosphite, carbon disulfide and sodium hydroxide, as the reduction in the number of stages of obtaining the target substance corresponds to a number of principles of «green» chemistry, and namely, principle 2, which reads: «The synthesis strategy must be chosen in such a way that all materials used in the synthesis process are maximized were included in the product», and also to principle 5, which reads: «The use of auxiliary substances (solvents, extractants, etc.) should be minimized whenever possible» $[2,3]$.

A four-component reaction of a single-reactor reaction of diethanolamine, dimethyl phosphite, carbon disulfide and sodium hydroxide, taken in a molar ratio of $1: 1: 1: 1$, was carried out in a ethyl alcohol medium at room temperature, as shown in the diagram in Figure 5. After appropriate treatment of the reaction mixture, sodium O-2-((dimethoxyphosphoryl)(2-hydroxyethyl)amino)ethylxanthate was isolated in a yield of $65 \%$, m.p. $78{ }^{\circ} \mathrm{C}$.

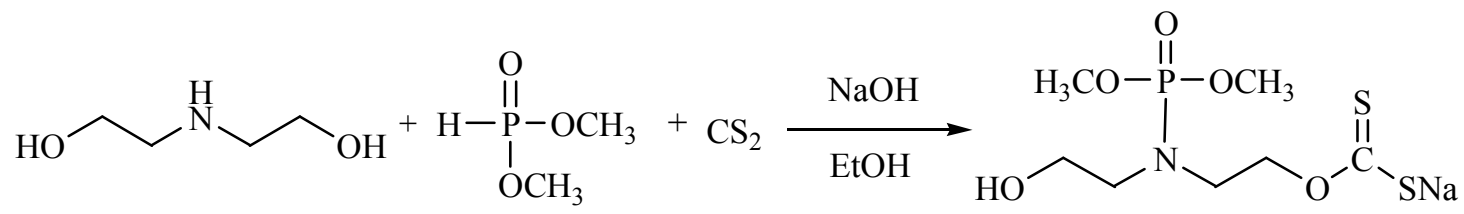

Figure 5. Scheme of a four-component reaction of a single-reactor interaction of diethanolamine, dimethylphosphite, carbon disulfide and sodium hydroxide

The structure of the synthesized samples of O-2-((dimethoxyphosphoryl)(2-hydroxyethyl)amino)ethyl xanthogenate was established on the basis of the IR and ${ }^{1} \mathrm{H}$ NMR spectra analysis [19]. In the IR spectra of both xanthate samples in the region of $2847 \pm 2952 \mathrm{~cm}^{-1}$, absorption bands characteristic for valence vibrations of $\mathrm{CH}_{2}$ and $\mathrm{CH}_{3}$ groups of saturated hydrocarbons are observed. A wide strong $\mathrm{OH}$ band absorption band is manifested in the $3300 \mathrm{~cm}^{-1}$ region. The absorption band of medium intensity in the region of $1201 \mathrm{~cm}^{-1}$ is attributed to the stretching vibrations of the $\mathrm{P}=\mathrm{O}$ group. Strong bands of stretching vibrations of $\mathrm{P}-\mathrm{O}-\mathrm{C}$ bonds are observed in the region of $1050 \mathrm{~cm}^{-1}$. The presence of the $\mathrm{C}=\mathrm{S}$ group is confirmed by the presence of very strong absorption bands in the spectrum at 1063 and $1070 \mathrm{~cm}^{-1}$, weak bands in the 781 and $575 \mathrm{~cm}^{-1}$ regions correspond to vibrations of the $\mathrm{C}-\mathrm{S}$ bond.

As a result of our studies, we have established that both the sequential reactions of diethanolamine phosphorylation and the interaction of the dimethylbis(2-hydroxyethyl)phosphoramidate formed with the carbon disulphide and the four-component reaction of the one-reactor interaction of diethanolamine, dimethylphosphite, carbon disulfide and sodium hydroxide form sodium O-2-((dimethoxyphosphoryl)(2-hydroxyethyl)amino)ethyl xanthate. The coincidence of the physicochemical characteristics of both xanthate samples confirms that in both cases the same substance was obtained. 
Consequently, the practical application of the principles of «green» chemistry leads to the synthesis of the desired compound: sodium O-2-((dimethoxyphosphoryl)(2-hydroxyethyl)amino)ethylxanthate by the atom economical method - with a reduction in the number of stages from two to one, and increase of the total yield of the target substance more than three times (from 19 to $65 \%$ ).

\section{The «green» method of monoethanolamine N-alkylation}

Continuing the search for highly effective flotation agents among amino alcohol derivatives, we investigated the «green» methods for the alkylation of monoethanolamine (MEA) in order to increase the yield of target products while reducing energy and labor costs [20]. Previously, the alkylation reaction of MEA was carried out by the usual method of amine reaction with alkyl bromide in the presence of potassium acetate in anhydrous alcohol at $50-55^{\circ} \mathrm{C}$ [21]. As a result of prolonged heating $(20-30 \mathrm{~h})$, corresponding $\mathrm{N}$-monosubstituted MEA derivatives with the yields of $27-42 \%$ and $\mathrm{N}, \mathrm{N}$-disubstituted derivatives of MEA with the yields of $7-10 \%$ are formed. Obviously, the use of the conventional alkylation process gives a rather low yield of the target amino alcohols with a total reaction time of 3-5 days. Therefore, a search for a more economical method of synthesis was carried out.

In order to optimize the conditions for the interaction of MEA with alkyl halides and increase the yield of $\mathrm{N}$-alkylation products, the reaction was carried out in various solvents - alcohol, acetone, dioxane, tetrahydrofuran, benzene. It has been experimentally established that $90 \%$ alcohol is the most suitable solvent. In fact, the solubility of the initial reagent - MEA in alcohol is greatest. While in other polar solvents such as sulfuric ether, ethyl acetate, dioxane, tetrahydrofuran, MEA is practically insoluble, or dissolves poorly at room temperature, which consequently affects the yield of the final product.

Among the tested binding agents of hydrogen bromide, which was released in the reaction, $-\mathrm{NaOH}$, $\mathrm{KOH}$, sodium and potassium acetate, potash, the best yields of alkylated ethanolamines were obtained by using potash. Based on the analysis of scientific chemical literature on the application of «green» chemistry methods, it has been shown that one of the main principles of «green» chemistry is the use of catalysts in order to shorten the time of synthesis, reduce energy costs and increase the selectivity of reactions for rational use of initial reagents and reduce the costs of target products [1-3].

Since the MEA alkylation reaction is carried out in a two-phase liquid-solid system, an organic catalyst for the interfacial transfer the tetrabutylammonium iodide was used. With the addition of five mole percent catalyst, the alkylation process is significantly accelerated, and the reaction ends after two hours at room temperature. As a result of the reaction, monosubstituted N-alkyl-N-ethanolamines in the yields of 72-81\% and disubstituted N,N-dialkyl ethanolamines in the yields of 7-19\% were obtained under the conditions obtained (Fig. 6). The composition of the obtained compounds was confirmed on the basis of elemental analysis data, and the structure was based on IR and NMR data of ${ }^{1} \mathrm{H}$ and ${ }^{13} \mathrm{C}$ spectroscopy [20].

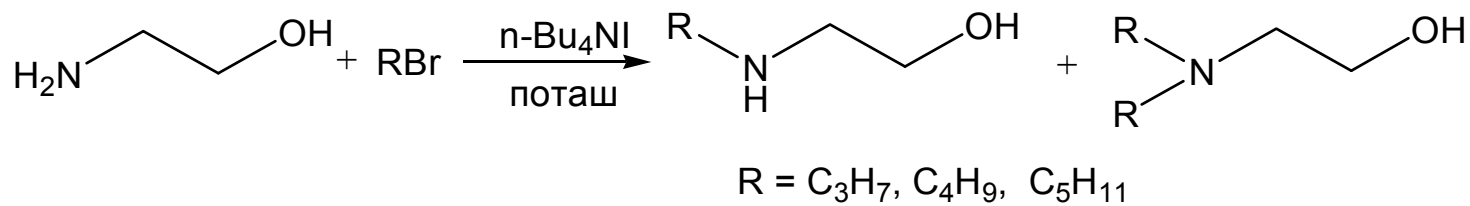

Figure 6. Synthesis of $\mathrm{C}_{3}-\mathrm{C}_{5}$ alkylated derivatives of MEA in «green» conditions

Thus, using the principles of «green» chemistry, carrying out the alkylation reaction of MEA in aqueous alcohol under organocatalysis conditions makes it possible to obtain $\mathrm{N}$-alkylated derivatives of MEA selectively and in high yield, with an almost doubling of the yield of the target substances and a reduction in the reaction time by a factor of ten.

\section{«Green» chemistry in the synthesis of sodium dimethoxyphosphoryloxyethyl carbamate}

With the aim of developing new highly effective flotation reagents-collectors, we investigated the reaction of phosphorylation of MEA [22]. In the study of various reaction conditions, the best conversion of the initial MEA was achieved by phosphorylation with dimethyl phosphite (DMF) at $80{ }^{\circ} \mathrm{C}$ in benzene using magnesium oxide as the catalyst and a molar ratio of reagents MEA:DMF:MgO $=1: 1: 1$. As a result of the reaction, 2-aminoethyldimethylphosphate (ADMP) was obtained in a yield of $65 \%$ (Fig. 7). 2-Aminoethyldimethylphosphate is an oil, that is highly soluble in water. 
<smiles>COP(=O)(OC)OCCN</smiles>

Figure 7. Phosphorylation of MEA by dimethyl phosphite

The composition and individuality of synthesized 2-aminoethyldimethylphosphate are confirmed by thin-layer chromatography and physicochemical characteristics. The structure of the compound was established on the basis of an analysis of the IR and NMR spectra of ${ }^{1} \mathrm{H}$ and ${ }^{13} \mathrm{C},{ }^{31} \mathrm{P}[22]$. In the IR spectrum of the synthesized phosphate, given in a Table, there is an absorption band of the characteristic vibrations of the $\mathrm{NH}_{2}$ group at $3440 \mathrm{~cm}^{-1}$, in the region of $1190 \mathrm{~cm}^{-1}$ a characteristic band of the $\mathrm{P}=\mathrm{O}$ group is observed, in the $1070 \mathrm{~cm}^{-1}$ the absorption band of $\mathrm{P}-\mathrm{O}-\mathrm{C}$. In the ${ }^{31} \mathrm{P} 2$-aminoethyldimethyl phosphate spectrum, only one signal is observed in the $6.72 \mathrm{ppm}$ region corresponding to the phosphate group.

In order to obtain new surfactants, we investigated the reaction of 2-aminoethyldimethylphosphate with carbon disulfide. The reaction was carried out in the presence of an equimolar amount of sodium hydroxide in an ethyl alcohol medium at room temperature, as shown in Figure 8. The reaction yielded a crystalline product in $48 \%$ yield, which is sodium 2-dimethoxyphosphoryloxyethylcarbamate (DMPC-1). At the same time, its total yield with respect to the initial MEA is $31 \%$.

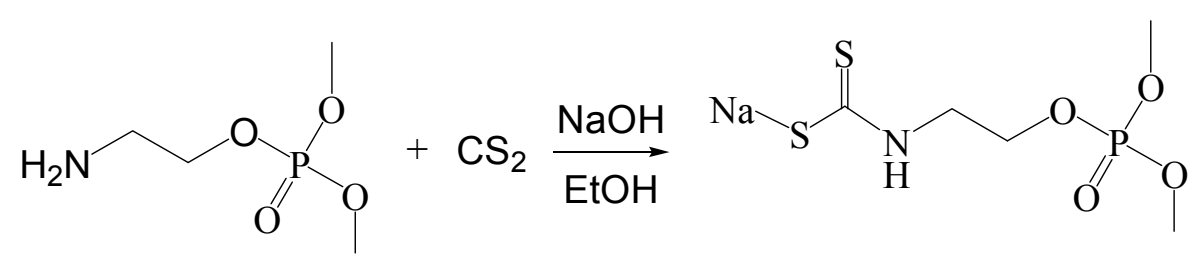

Figure 8. Interaction of 2-aminoethyldimethylphosphate with carbon disulfide

The structure and individuality of the synthesized compound - sodium 2-dimethoxyphosphoryloxyethylcarbamate - are confirmed by the data of physicochemical methods, IR and PMR spectroscopy [22], presented in Table.

In order to develop a «green» method for the synthesis of sodium 2-dimethoxyphosphoryloxyethylcarbamate, we carried out a four-component reaction of monoethanolamine, dimethylphosphite, carbon disulfide and sodium hydroxide, due to the fact that the reduction in the number of stages of obtaining the target substance corresponds to a number of principles of «green» chemistry $[2,3]$.

The four-component reaction of single-reactor method of MEA, DMF, carbon disulfide and sodium hydroxide in a molar ratio of 1:1:1:1 interaction was carried out in an ethyl alcohol medium at room temperature, as shown in the scheme in Figure 9. After the appropriate treatment of the reaction mixture, 2-dimethoxyphosphoryloxyethylcarbamate (DMFC-2) in $78 \%$ yield.<smiles>COP(=O)(OC)OCCNC(=S)S[As]</smiles>

Figure 9. The single-reactor method of four-component reaction of MEA, DMF, carbon disulfide and sodium hydroxide

As can be seen from the data in Table, the infrared spectra and nuclear magnetic resonance spectra of ${ }^{1} \mathrm{H}$ and ${ }^{13} \mathrm{C}$ of the sample of sodium 2-dimethoxyphosphoryloxyethyl carbamate (DMPC-2) obtained in the four-component reaction coincide with the spectra of the sample obtained in the reaction of 2aminoethyldimethylphosphate with carbon disulfide DMPC-1. 
Physico-chemical characteristics of synthesized MEA derivatives

\begin{tabular}{|c|c|c|c|c|c|c|c|c|}
\hline \multirow{2}{*}{$\begin{array}{c}\text { MEA } \\
\text { derivatives }\end{array}$} & A yield \% & \multirow{2}{*}{$\mathrm{R}_{\mathrm{f}}$} & \multicolumn{3}{|c|}{ PMR spectra data, $\delta, \mathrm{ppm}$} & \multicolumn{3}{|c|}{ IR spectra data, $v, \mathrm{sm}^{-1}$} \\
\cline { 5 - 9 } & $\begin{array}{c}\mathrm{CH}_{2} \mathrm{NH}_{2} \\
\left(\mathrm{CH}_{2} \mathrm{NH}\right)\end{array}$ & $\mathrm{OCH}_{3}$ & $\mathrm{OCH}_{2}$ & $\mathrm{P}=\mathrm{O}$ & $\mathrm{P}-\mathrm{O}-\mathrm{C}$ & $\mathrm{NH}_{2}(\mathrm{NH})$ \\
\hline ADMP & 65 & 0.17 & 2.95 & $3.24-3.27$ & 3.58 & 1190 & 1070 & 3440 \\
\hline DMPC-1 & 48 & 0.28 & $(4.50)$ & $3.26-3.28$ & 3.62 & 1163 & 1050 & $(3414)$ \\
\hline DMPC-2 & 78 & 0.29 & $(4.50)$ & $3.27-3.31$ & 3.62 & 1200 & 1053 & $(3425)$ \\
\hline
\end{tabular}

Thus, we have established that as a result of sequential reactions of phosphorylation of monoethanolamine and subsequent reaction of the 2-aminoethyldimethylphosphate formed with carbon disulphide and the four-component reaction of monoethanolamine, dimethyl phosphite, carbon disulfide and sodium hydroxide, a sodium 2-dimethoxyphosphoryloxyethyl carbamate is formed. In the latter case, its total yield increases in 2.5 times. Consequently, the application of the principles of «green» chemistry makes it possible to carry out the synthesis by an atom-economic method with a reduction in the number of stages from two to one and a significant increase in the yield of the target substance.

\section{References}

1 Шелдон Р.А. Каталитические превращения в воде и сверхкритическом диоксиде углерода с позиций концепции устойчивого развития / Р.А. Шелдон // Рос. хим. журн. - 2004. — Т. 48, № 6. - С. 74-83.

2 Кустов Л.М. «Green Chemistry» — новое мышление / Л.М. Кустов, И.П. Белецкая // Рос. хим. журн. — 2004. — Т. 48, № 6. - C. 3-12.

3 Anastas P. The Role of Catalysis in the Design, Development and Implementation of Green Chemistry / P. Anastas, L.B. Bartlett, M.M. Kirchhoff, T.C. Williamson // Catalysis Today. — 2000. — Vol. 55, No. 1-2. — P. 11-22.

4 Абрамов А.А. Флотационные методы обогащения / А.А. Абрамов. - М.: Изд-во Моск. гос. горного ун-та; Горная кн.; Мир горной кн., 2008. - 710 с.

5 Абрамов А.А. Собрание сочинений. Т.7. Флотация. Реагенты-собиратели / А.А. Абрамов. - М.: Изд-во Моск. гос. горного ун-та, 2010. - $656 \mathrm{c.}$

6 Абрамов А.А. Пути развития теории обогатительных процессов и создания инновационных технологий комплексного использования сырья / А.А. Абрамов // Физико-технические проблемы разработки полезных ископаемых. - 2012. № 1. - С. $165-178$.

7 Калугин С.Н. Химия и технология получения флотореагентов / С.Н. Калугин. - Алматы: Каз. ун-т, 2014. — 230 с.

8 Шубов Л.Я. Флотационные реагенты в процессах обогащения минерального сырья / Л.Я. Шубов, С.И. Иванков, Н.К. Щеглова. - В 2 кн. Кн. 1. — М.: Недра, 1990. — 400 с.

9 Абрамов А.А. Принципы выбора и синтеза более селективных собирателей во флотации / А.А. Абрамов, М.М. Сорокин // Цветные металлы. - 2009. — № 4. - С. 35-40.

10 Игнаткина В.А. Выбор селективных собирателей для флотации сульфидных минералов / В.А. Игнаткина // Цветные металлы. - 2009. - № 6. - С. 14-19.

11 Рябой В.И. Создание и применение более эффективных реагентов на основе физико-химических представлений / В.И. Рябой // Обогащение руд. — 2002. — № 1. - С. 19-23. $191 \mathrm{c}$.

12 Чантурия В.А. Химия поверхностных явлений при флотации / В.А. Чантурия, Р.Ш. Шафеев. — М.: Недра, 1977. -

13 Рубцов Н.В. Эффективность сочетаний ксантогенатов / Н.В. Рубцов, В.М. Усова // Технология обогащения полиметаллических руд: сб. науч. тр. ВНИИцветмет. - М.: Недра, 1972. - С. 132-136.

14 Ержанов К.Б. Инновационный патент РК № 26888. Динатриевая соль N-октил-N,N-бис(2-ксантогенатэтил)амина, обладающая флотационной активностью при обогащении сульфидных руд / К.Б. Ержанов, Н.О. Акимбаева, И.Н. Ануарбекова, Н.К. Тусупбаев, Ж.А. Ержанова, А.А. Муханова // БИ. — 2013. — № 5.

15 Ержанов К.Б. Инновационный патент РК № 28114. 2-[N-гептил-N-(2-гидроксиэтил)амино] этилксантогенат натрий, обладающий флотационной активностью / К.Б. Ержанов, Н.О. Акимбаева, И.Н. Ануарбекова, Н.К. Тусупбаев, Ж.А. Ержанова, А.А. Муханова // БИ. — 2014. — № 2.

16 Ергожин Е.Е. Инновационный патент РК № 26889. ,N-Ди(2-гидроксиэтил)аминононан, обладающий флотационной активностью при обогащении сульфидных руд / Е.Е. Ергожин, К.Б. Ержанов, Н.О. Акимбаева, И.Н. Ануарбекова, Н.К. Тусупбаев, Ж.А. Ержанова, А.А. Муханова // БИ. — 2013. — № 5.

17 Ержанов К.Б. Отчет о научно-исследовательской работе «Разработка технологии получения новых поверхностноактивных веществ на основе продуктов переработки углеводородного сырья», по научно-технической программе О.0537-03 «Научное обеспечение развития химической промышленности Республики Казахстан на 2010-2012 годы», 1 направление переработка углеводородного сырья и нефтехимия, раздел 3 «Разработка и реализация технологий переработки углеводородного сырья с целью получения мономеров, полимеров и поверхностно-активных веществ». № Гос. регистрации 0110РК00199, отчеты в НЦНТИ под инв. номерами 0210РК01118 (2010г.), 211РК00730 (2011г.) 0212 РК00833 (2012 г.)/ К.Б. Ержанов, Н.Б. Курманкулов, С.А. Визер и др. 
18 Akimbaeva N.O. Application of «green» chemistry’s principles at the N-alkylation of diethanolamine / N.O. Akimbaeva, I.N. Anuarbekova, S.A. Vizer, K.B. Yerzhanov // Хим. журн. Каз. - 2016. — № 2(54). — С. 183-188.

19 Акимбаева Н.О. Промежуточный отчет по гранту «Исследование и разработка «зеленых» условий синтеза отечественных высокоэффективных и селективных флотореагентов на основе местного сырья для обогащения труднообогатимых полиметаллических и золотосодержащих руд» по бюджетной программе Г.2015 «Развитие науки», № гос. регистрации 0115РК00252, отчет в НЦНТИ, инв. номер 0216РК01536 (2016 г.) / Н.О. Акимбаева, К.Б. Ержанов, С.А. Визер, И.Н. Ануарбекова, М.С. Муканова, Е.С. Сычева.

20 Акимбаева Н.О. Изучение «зеленых» методов N-алкилирования моноэтаноламина / Н.О. Акимбаева, С.А. Визер, И.Н. Ануарбекова, Т.М. Сейлханов, К.Б. Ержанов // Хим. журн. Каз. - 2016. — № 4. — С. 302-308.

21 Ануарбекова И.Н. Синтез N(алкил)-N-моноэтаноламинов на основе первичного амина / И.Н. Ануарбекова, Н.О. Акимбаева, Н.Б. Курманкулов // Инновационные технологии и исследования, направленные на развитие «зеленой» энергетики и глубокую переработку продукции: сб. материалов междунар. шк.-семинара. — Усть-Каменогорск, 2013. — C. 64.

22 Акимбаева Н.О. Применение методов «зеленой» химии в синтезе фосфорилоксиэтилкарбамата натрия / Н.О. Акимбаева, Е.С. Сычева, С.А. Визер, К.Б. Ержанов // Хим. журн. Каз. - 2017. — № 2. — С. 243-250.

\title{
С.А. Визер, Н.О. Әкімбаева, Қ.Б. Ержанов \\ Флотореагенттер синтезіндегі «жасыл» химия әдістері
}

\begin{abstract}
Мақалада потенциалды беттік белсенді заттар және флотореагенттер болып табылатын моноэтаноламин мен диэтаноламиннің әртүрлі туындыларының синтезіне «жасыл» химия әдістерін жасауға арналған авторлардың өз жұмыстарына шолу жүргізілген. Онда «жасыл» химия принциптерін қолданғанда мақсатталған өнімнің шығымдары біршама (екі-үш есеге) жоғарылайтыны және процесті жүргізу температурасы мен реакция жүргізу ұзақтығы он есе төмендеуі біршама энергетикалық және еңбек шығындардың қысқаруына әкелген. Атомэкономды әдіспен мақсатталған флотореагенттердің синтезі - саты саны екіден бірге дейін қысқартып, сонымен қатар мақсатталған заттың жалпы шығымын 2-3 есеге дейін жоғарылатуға қабілеттілігін көрсеткен.
\end{abstract}

Кілт сөздер: беттік белсенді заттар, флотореагенттер, «жасыл» химия, моноэтаноламин және диэтаноламиндердің алкилді және диалкоксифосфорил туындылары, ксантогенат, карбамат.

\section{С.А. Визер, Н.О. Акимбаева, К.Б. Ержанов}

\section{«Зеленые» методы химии в синтезе флотореагентов}

\begin{abstract}
В статье проведен обзор собственных работ авторов, посвященных разработке «зеленых» методов химии в синтезе разнообразных производных моноэтаноламина и диэтаноламина, являющихся потенциальными поверхностно-активными веществами и флотореагентами. Показано, что применение принципов «зеленой» химии позволяет значительно (в два-три раза) повысить выходы целевых веществ при десятикратном сокращении продолжительности проведения реакций и снижении температуры проведения процессов, что приводит к значительному сокращению энергетических и трудовых затрат. Синтез целевых флотореагентов атомэкономным методом - с сокращением числа стадий от двух до одной также способствует повышению общего выхода целевых веществ в 2-3 раза.
\end{abstract}

Ключевые слова: поверхностно-активные вещества, флотореагенты, «зеленая» химия, алкильные и диалкоксифосфорильные производные моноэтаноламина и диэтаноламина, ксантогенат, карбамат.

\section{References}

1 Sheldon, R.A. (2004). Kataliticheskie prevrashcheniia v vode i sverkhkriticheskom diokside uhgleroda s pozitsii kontseptsii ustoichivoho razvitiia [Catalytic transformations in water and supercritical carbon dioxide from the standpoint of the concept of sustainable development]. Rossiiskii khimicheskii zhurnal - Russian Chemical Journal, 48, 6, 74-83 [in Russian].

2 Kustov, L.M., \& Beletskaya, I.P. (2004). «Green Chemistry» — novoe myshlenie [«Green Chemistry» — a new thinking]. Rossiiskii khimicheskii zhurnal - Russian Chemical Journal, 48, 6, 3-12 [in Russian].

3 Anastas, P., Bartlett, L.B., Kirchhoff, M.M., \& Williamson, T.C. (2000). The Role of Catalysis in the Design, Development and Implementation of Green Chemistry. Catalysis Today, 55, 1-2, 11-22.

4 Abramov, A.A. (2008). Flotatsionnye metody obohashcheniia [Flotation methods of enrichment]. Moscow: Publ. house of Moscow State Mining University; Publishing house «Hornaia kniga», «Mir hornoi knigi» [in Russian].

5 Abramov, A.A. (2010). Sobranie sochinenii. T. 7. Flotatsiia. Reagenty-sobirateli [Collected works. Vol. 7. Flotation. Reagents-collectors]. Moscow: Publ. house of Moscow State Mining University [in Russian]. 
6 Abramov, A.A. (2012). Puti razvitiia teorii obohatitelnykh protsessov i sozdaniia innovatsionnykh tekhnolohii kompleksnoho ispolzovaniia syria [Ways of development of the theory of enrichment processes and the creation of innovative technologies for the integrated use of raw materials]. Fiziko-tekhnicheskie problemy razrabotki poleznykh iskopaemykh — Physico-technical problems of mining, 1, 165-178 [in Russian].

7 Kalugin, S.N. (2014). Khimiia i tekhnolohiia polucheniia flotoreahentov [Chemistry and technology of obtaining flotation agents]. Almaty: Kazakh University [in Russian].

8 Shubov, L.Ya., Ivankov, S.I., \& Scheglova, N.K. (1990). Flotatsionnye reahenty v protsessakh obohashcheniia mineralnoho syria [Flotation reagents in the processes of mineral dressing]. (In 2 books. Book 1). Moscow: Nedra [in Russian].

9 Abramov, A.A., \& Sorokin, M.M. (2009). Printsipy vybora i sinteza bolee selektivnykh sobiratelei vo flotatsii [Principles of selection and synthesis of more selective collectors in flotation]. Tsvetnye metally - Non-ferrous metals, 4, 35-40 [in Russian].

10 Ignatkina, V.A. (2009). Vybor selektivnykh sobiratelei dlia flotatsii sulfidnykh mineralov [Selection of selective collectors for the flotation of sulphide minerals]. Tsvetnye metally - Non-ferrous metals, 6, 14-19 [in Russian].

11 Riaboy, V.I. (2002). Sozdanie i primenenie bolee effektivnykh reagentov na osnove fiziko-khimicheskikh predstavlenii [Creation and application of more effective reagents on the basis of physical and chemical representations]. Obogashchenie rud - Enrichment of ores, 1, 19-23 [in Russian].

12 Chanturia, V.A., \& Shafeev, R.Sh. (1977). Khimiia poverkhnostnykh yavlenii pri flotatsii [Chemistry of surface phenomena in flotation]. Moscow: Nedra [in Russian].

13 Rubtsov, N.V., \& Usova, V.M. (1972). Effektivnost sochetanii ksantohenatov [Efficiency of combinations of xanthates]. Tekhnolohiia obohashcheniia polimetallicheskikh rud - Technology of enrichment of polymetallic ores. Moscow: Nedra [in Russian].

14 Erzhanov, K.B., Akimbaeva, N.O., Anuarbekova, I.N., Tusupbaev, N.K., Yerzhanova, Zh.A., \& Mukhanova, A.A. (2013). Innovatsionnyi patent RK № 26888. Dinatrievaia sol N-oktil-N,N-bis(2-ksantogenatetil)amina, obladaiushchaia flotatsionnoi aktivnostiu pri obohashchenii sulfidnykh rud [Innovation Patent of the Republic of Kazakhstan No. 26888. Disodium salt of N-octyl$\mathrm{N}, \mathrm{N}$-bis(2-xanthate ethyl)amine, which has flotation activity in the enrichment of sulphide ores]. Biulleten izobretenii - Bulletin, 5 [in Russian].

15 Erzhanov, K.B., Akimbaeva, N.O., Anuarbekova, I.N., Tusupbaev, N.K., Erzhanova Zh.A., \& Mukhanova A.A. (2014). Innovatsionnyi patent RK № 28114. 2-[N-geptil-N-(2-gidroksietil)amino]etilksantohenat natrii, obladaiushchii flotatsionnoi aktivnostiu [Innovation Patent of the Republic of Kazakhstan No. 28114. 2-[N-heptyl-N-(2-hydroxyethyl)amino] ethylxanthate sodium, having flotation activity]. Biulleten izobretenii - Bulletin, 2 [in Russian].

16 Ergozhin E.E., Erzhanov K.B., Akimbaeva N.O., Anuarbekova I.N., Tusupbaev N.K., Erzhanova Zh.A., \& Mukhanova A.A. (2013). Innovatsionnyi patent RK № 26889. N,N-Di(2-gidroksietil)aminononan, obladaiushchii flotatsionnoi aktivnostiu pri obohashchenii sulfidnykh rud [Innovation patent of Republic of Kazakhstan № 26889. N,N-Di(2-hydroxyethyl)aminononane, which has a flotation activity in the enrichment of sulphide ores]. Biulleten izobretenii - Bulletin, 5 [in Russian].

17 Erzhanov, K.B., Kurmankulov, N.B., \& Vizer, S.A., et al. (2012). Otchet o nauchno-issledovatelskoi rabote «Razrabotka tekhnolohii polucheniia novykh poverkhnostno-aktivnykh veshchestv na osnove produktov pererabotki uhlevodorodnoho syria», po nauchno-tekhnicheskoi prohramme O.0537-03 «Nauchnoe obespechenie razvitiia khimicheskoi promyshlennosti Respubliki Kazakhstan na 2010-2012 hody», 1 napravlenie - pererabotka uhlevodorodnoho syria i neftekhimiia, razdel 3 «Razrabotka $i$ realizatsiia tekhnolohii pererabotki uplevodorodnoho syria s tseliu polucheniia monomerov, polimerov i poverkhnostno-aktivnykh veshchestv». № Gos. rehistratsii 0110RK00199, otchety v NTsNTI pod inv. nomerami 0210RK01118 (2010 g.), 211 RK00730 (2011 g.) 0212 RK00833 (2012 g.) [Report on the research work «Development of technology for obtaining new surfactants based on hydrocarbon feedstock products», on the scientific and technical program 0.0537-03 «Scientific provision of development of the chemical industry of the Republic of Kazakhstan for 2010-2012», 1st direction - Processing of hydrocarbon raw materials and petrochemistry, Section 3 - Development and implementation of hydrocarbon processing technologies for the production of monomers, polymers and surfactants. State. registration No. 0110RK00199, reports in the NCSTI under Inv. numbers 0210RK01118 (2010), 0211RK00730 (2011) 0212RK00833] [in Russian].

18 Akimbaeva, N.O., Anuarbekova, I.N., Vizer, S.A., \& Yerzhanov, K.B. (2016). Application of «green» chemistry's principles at the N-alkylation of diethanolamine. Chem. J. Kaz., 2(54), 183-188.

19 Akimbaeva, N.O., Erzhanov, K.B., Vizer, S.A., Anuarbekova, I.N., Mukanova, M.S., \& Sycheva, E.S. (2016). Promezhutochnyi otchet po hrantu "Issledovanie $i$ razrabotka «zelenykh» uslovii sinteza otechestvennykh vysokoeffektivnykh $i$ selektivnykh flotoreahentov na osnove mestnoho syria dlia obohashcheniia trudnoobohatimykh polimetallicheskikh $i$ zolotosoderzhashchikh rud» po biudzhetnoi programme G.2015 «Razvitie nauki», № hos. rehistratsii 0115RK00252, otchet $v$ NTsNTI, inv. nomer 0216RK01536 [Interim report on the grant "Research and development of» green "conditions for the synthesis of domestic highly effective and selective flotation agents based on local raw materials for the enrichment of difficult-to-digestible polymetallic and gold-bearing ores» under the budget program G.2015 «Development of Science», registration No. 0115RK00252, report in the NCISTI, inv. number 0216PK01536] [in Russian].

20 Akimbaeva, N.O., Vizer, S.A., Anuarbekova, I.N., Seilkhanov, T.M., \& Erzhanov, K.B. (2016). Izuchenie «zelenykh» metodov N-alkilirovaniia monoetanolamina [The study of «green» methods of $\mathrm{N}$-alkylation of monoethanolamine]. Khimicheskii zhurnal Kazakhstana - Chem. J. Kaz., 4, 302-308 [in Russian].

21 Anuarbekova, I.N., Akimbaeva, N.O., \& Kurmankulov, N.B. (2013). Sintez N(alkil)-N-monoetanolaminov na osnove pervichnoho amina [Synthesis of N(alkyl)-N-monoethanolamines based on the primary amine]. Proceedings from Innovative technologies and research aimed at the development of green energy and deep processing of products'13: Mezhdunarozhdnaia shkolaseminar - Int. school-seminar (p. 64). Ust-Kamenogorsk [in Russian].

22 Akimbaeva, N.O., Sycheva, E.S., Vizer, S.A., \& Erzhanov, K.B. (2017). Primenenie metodov «zelenoi» khimii v sinteze fosforiloksietilkarbamata natriia [Application of the methods of "green» chemistry in the synthesis of sodium phosphoryloxyethylcarbamate]. Khimicheskii zhurnal Kazakhstana-Chem. J. Kaz., 2, 243-250 [in Russian]. 